https://doi.org/10.18778/1509-877X.2021.02.02

\title{
WYKONANIE ZASTĘPCZE A ODLICZENIE VAT
}

Streszczenie. Przedmiotem artykułu są zagadnienia związane z prawem do odliczenia podatku od towarów i usług (VAT) w związku z nabyciem przez podatnika VAT towarów lub usług od wykonawców zastępczych. Autorka wskazuje wiele wątpliwości wynikających ze stanowiska zajmowanego w tej sprawie przez organy podatkowe, które kwestionują prawo podatnika do odliczenia VAT w takich przypadkach. Ponadto zwraca uwagę, że przyjęte przez organy podatkowe stanowisko, zgodnie z którym nabycie towarów i usług od wykonawców zastępczych z założenia nie jest związane z działalnością gospodarczą podatnika, lecz z czynnościami niepodlegającymi opodatkowaniu VAT, a w konsekwencji VAT od nabytych towarów i usług nie podlega odliczeniu - jest błędne. W artkule wskazuje się, że nabycie w warunkach wykonania zastępczego jest związane z działalnością gospodarczą podatnika i służy bezpośrednio realizacji tej działalności. Nie zmienia się bowiem przeznaczenie nabywanych przez podatnika towarów i usług. Jeżeli nabycie towarów lub usług od pierwotnie wybranego wykonawcy byłoby związane z działalnością gospodarczą podatnika, to nabycie towarów lub usług od wykonawców zastępczych również będzie z tą działalnością związane. Zmiana podmiotu realizującego usługi (dokonującego dostawy) nie zmienia celu ich nabycia przez podatnika ani ich związku z prowadzoną przez niego działalnością gospodarczą. Podatnik powinien mieć prawo do odliczenia VAT w związku z nabyciem w warunkach wykonania zastępczego. Prawo podatnika do odliczenia VAT powinno mieć przełożenie na wysokość rekompensaty od dłużnika (niesolidnego wykonawcy) z tytułu wykonania zastępczego, a nie odwrotnie.

Słowa kluczowe: VAT, wykonanie zastępcze, odliczenie podatku, odszkodowanie

* Doradca podatkowy, ekspert Instytutu Odpowiedzialnych Finansów, of counsel w Kancelarii Prawniczej Stolarek i Wspólnicy, e-mail: hanna.majszczyk@msag.pl

\section{@creative}


Odliczenie podatku od towarów i usług (dalej: VAT) jest podstawowym prawem podatnika tego podatku (dalej: podatnik lub podatnik VAT), realizującym jednocześnie zasadę neutralności VAT dla jego podatników. Warunki, jakie musi spełniać podatnik w celu dokonania tego odliczenia, określone zostały w art. 86-88 ustawy o podatku od towarów i usług ${ }^{1}$. Podstawowym warunkiem dla dokonania przez podatnika takiego odliczenia jest związek pomiędzy nabyciem towarów i usług z prowadzoną przez podatnika działalnością gospodarczą, działalnością opodatkowaną. Na tym tle wiele wątpliwości budzi możliwość odliczenia VAT przez podatników dokonujących nabycia towarów i usług w warunkach wykonania zastępczego. Chodzi tu o podatników, u których nabycie towarów lub usług od pierwotnie wybranego kontrahenta (wykonawcy) byłoby związane z prowadzoną przez podatnika opodatkowaną działalnością gospodarczą.

Uwzględniając dość jednolitą linię interpretacyjną organów podatkowych (interpretacje indywidualne Dyrektora Krajowej Informacji Skarbowej - DKIS), w zasadzie można powiedzieć, że nie uznaje się prawa podatnika do odliczenia VAT naliczonego przy nabyciu towarów i usług w warunkach wykonania zastępczego. Stanowisko takie znajduje również potwierdzenie w części orzecznictwa sądów administracyjnych (co do zasady, w odniesieniu do sytuacji, gdy dochodzi do zaniechania wykonania zobowiązań przez pierwszego wykonawcę jego zobowiązań w związku $\mathrm{z}$ udzieloną gwarancją lub rękojmią). Analiza indywidualnych interpretacji podatkowych i orzecznictwa sądów w omawianym zakresie nasuwa jednak wiele wątpliwości co do zasadności przyjmowanego stanowiska.

2. WYKonANIE ZASTĘPCZE - DLACZEgo KWESTIONUJE SIĘ PRAWO DO ODLICZENIA VAT Z FAKTUR OD WYKONAWCÓW ZASTĘPCZYCH

Wykonanie zastępcze reguluje przepis art. 480 Kodeksu cywilnego ${ }^{2}$.Zgodnie z tym przepisem, $\mathrm{w}$ razie zwłoki dłużnika w wykonaniu zobowiązania czynienia, wierzyciel może, zachowując roszczenie o naprawienie szkody, żądać upoważnienia przez sąd do wykonania czynności na koszt dłużnika (\$1). Jeżeli

1 Ustawa z dnia 11 marca 2004 r. o podatku od towarów i usług (tekst jedn. Dz.U. z 2021 r., poz. 685 ze zm.), dalej: ustawa VAT.

${ }^{2}$ Ustawa z dnia 23 kwietnia 1964 r. - Kodeks cywilny (tekst jedn. Dz.U. z 2020 r., poz. 1740), dalej: k.c. 
świadczenie polega na zaniechaniu, wierzyciel może, zachowując roszczenie o naprawienie szkody, żądać upoważnienia przez sąd do usunięcia na koszt dłużnika wszystkiego, co dłużnik wbrew zobowiązaniu uczynił $(\$ 2)$. W przypadkach nagłych wierzyciel może, zachowując roszczenie o naprawienie szkody, wykonać bez upoważnienia sądu czynność na koszt dłużnika lub usunąć na jego koszt to, co dłużnik wbrew zobowiązaniu uczynił (\$3).

Sytuacje, w których może dochodzić do wykonania zastępczego, są oczywiście bardzo różne. Nabycie w warunkach wykonania zastępczego może dotyczyć sytuacji, w których wykonawca zastępczy wykonuje czynności, które gdyby były wykonane przez pierwotnie wybranego wykonawcę (kontrahenta), byłyby opodatkowane podatkiem VAT, oraz takich, w których wykonanie czynności przez pierwotnie wybranego wykonawcę (kontrahenta) nie wiązałoby się z obciążeniem zamawiającego kwotami VAT (np. czynności wykonywane w związku z udzieloną gwarancją lub rękojmią). Jak wynika $z$ analizy orzeczeń sądów (o czym będzie mowa w dalszej części opracowania), to, jakiej sytuacji dotyczy wykonanie zastępcze, ma bezpośrednie przełożenie na zajmowane przez sądy stanowisko co do możliwości odliczenia przez podatnika kwoty VAT z faktur wystawionych przez wykonawców zastępczych.

Z przeglądu indywidualnych interpretacji podatkowych wynika, że uznaje się, iż podatnikowi nie przysługuje prawo do obniżenia kwoty podatku należnego o kwoty VAT wynikające $\mathrm{z}$ faktur wystawianych przez wykonawców zastępczych, gdyż zdaniem organów nie zachodzi związek pomiędzy nabyciem $\mathrm{w}$ ramach wykonania zastępczego $\mathrm{z}$ opodatkowaną działalnością gospodarczą podatnika. Nabycie takie traktuje się jako związane z czynnościami niepodlegającymi opodatkowaniu podatkiem VAT. Zgodnie $\mathrm{z}$ zajmowanym przez organy stanowiskiem obciążenie podatnika kosztami wykonawstwa zastępczego nie jest związane $\mathrm{z}$ wykonywaniem przez niego czynności opodatkowanych, nie jest związane z prowadzoną przez niego działalnością gospodarczą. Zwrot kosztów wykonania zastępczego ma charakter odszkodowawczy i stanowi formę rekompensaty. Nie stanowi tym samym wynagrodzenia za usługę podlegającą opodatkowaniu podatkiem VAT. Dlatego też, zdaniem organów, brak związku pomiędzy nabyciem usług (towarów) realizowanych w ramach wykonania zastępczego z czynnościami opodatkowanymi.

Powyższe znajduje potwierdzenie w licznych indywidualnych interpretacjach podatkowych Dyrektora Krajowej Informacji Skarbowej, np. z dnia 10 maja 2017 r., nr 0461-ITPP3.4512.84.2017.2.AB, z dnia 10 stycznia 
2020 r., nr 0113-KDIPT1-2.4012.593.2019.2.KW, z dnia 30 lipca 2020 r., nr 0114-KDIP4-3.4012.239.2020.1.KM. Przykładowo w interpretacji z dnia 30 lipca 2020 r. organ wskazuje, że: „Wnioskodawca składając pozew o zapłatę przez Wykonawcę tytułem zwrotu kosztów wykonania zastępczego w związku z niewywiązaniem się przez niego ze swoich obowiązków (tj. Wykonawca przerwał realizowanie usługi, nie wskazał innych niż należące do niego instalacji dla odbioru i przetwarzania odpadów), z późniejszym otrzymaniem zwrotu tych kosztów nie będzie wykonywać - w świetle ustawy o podatku od towarów i usług - żadnej czynności podlegającej opodatkowaniu podatkiem od towarów i usług. Wnioskodawca angażując podmiot trzeci (wykonawcę zastępczego) nie czyni tego w celach zarobkowych, lecz w celu uniknięcia skutków niesolidnego wykonania przez Wykonawcę zobowiązań wynikających z zawartej umowy.

W związku z powyższym, przyszłe otrzymanie zwrotu kosztów przez Wnioskodawcę, w związku ze złożeniem pozwu, nie będzie podlegać opodatkowaniu podatkiem od towarów i usług. Tym samym, nabyta usługa od wykonawcy zastępczego związana jest w sposób bezpośredni z czynnościami niepodlegającymi opodatkowaniu podatkiem od towarów i usług. W konsekwencji, Wnioskodawcy nie przysługuje prawo do odliczenia podatku naliczonego od przedmiotowych wydatków, ponieważ - wbrew twierdzeniu Wnioskodawcy - nie są one wykorzystywane do wykonywania czynności opodatkowanych podatkiem od towarów i usług" (podkreśl. H.M.).

Stanowisko takie znajduje potwierdzenie również w wyroku Naczelnego Sądu Administracyjnego (NSA) z dnia 21 października 2014 r., sygn. I FSK 1571/13 (CBOSA). Warto jednak zwrócić uwagę na wyrok NSA z dnia 6 lipca 2017 r., sygn. I FSK 2173/15 (CBOSA). W wyroku tym NSA - odmiennie, niż wynika to $\mathrm{z}$ interpretacji podatkowych - wskazuje, że istnieje związek pomiędzy nabyciem w ramach wykonania zastępczego a działalnością gospodarczą podatnika. NSA wskazał wszakże, że podatnikowi nie przysługuje prawo do odliczenia VAT z faktur od wykonawców zastępczych, jeżeli czynności wykonane przez wykonawcę zastępczego nie wiązałyby się z obciążeniem podatnika podatkiem VAT, gdyby były wykonane przez dłużnika (podatnika, który nie wykonał zobowiązania umownego). NSA uznał, że w takim przypadku podatek powinien zostać objęty kwotą odszkodowania należnego od niesolidnego kontrahenta. Ponadto stwierdził, że: „W konsekwencji, niesolidny podwykonawca (jako dłużnik) powinien generalnemu wykonawcy zwrócić pełne koszty wykonawstwa 
zastępczego, a więc ponieść ciężar ekonomiczny wykonanych za niego prac i poniesionych wydatków, w tym także w zakresie podatku od towarów i usług wykazanego przez wykonawcę zastępczego. Gdyby bowiem wykonał swoje zobowiązanie wobec generalnego wykonawcy, ten nie zostałby obciążony kwotą tego podatku, a zatem należność ta stanowi element świadczenia odszkodowawczego od dłużnika na rzecz wierzyciela”.

Jednocześnie NSA uznał, że sytuacja taka rzutuje wprost na prawo podatnika do odliczenia podatku. Można zatem założyć, że zdaniem Sądu, gdyby podatnik był obciążony podatkiem VAT w przypadku zrealizowania zamówionych świadczeń przez pierwotnie wybranego wykonawcę, przy dokonaniu nabycia tych świadczeń od wykonawców zastępczych przysługiwałoby mu prawo do odliczenia VAT wynikającego z faktur od nich otrzymanych.

W omawianym wyroku NSA stwierdził również, że: „5.4. Oczywiście poniesienie kosztów wykonawstwa zastępczego przez generalnego wykonawcę jest bezpośrednio związane ze świadczeniem odszkodowawczym należnym od niesolidnego podwykonawcy, lecz nie stanowi celu samego w sobie, gdyż usługa wykonawcy zastępczego jest także związana z realizacją obowiązków, jakie spoczywają na generalnym wykonawcy wobec inwestorów, a więc z szeroko pojętymi, realizowanymi przez niego czynnościami opodatkowanymi. Skoro jednak ich zrekompensowanie - w okolicznościach takich, jak w tej sprawie - powinno nastąpić w ramach świadczenia odszkodowawczego obejmującego kwotę należnego VAT, rzutuje to na prawo podatnika do odliczenia tego podatku.

5.5. Stwierdzić zatem należy, że podatek wynikający z faktury wystawionej przez wykonawcę zastępczego na rzecz generalnego wykonawcy, z tytułu usługi wykonanej za niesolidnego podwykonawcę, nie podlega odliczeniu na podstawie art. 86 ust. 1 ustawy z dnia 11 marca 2004 r. o podatku od towarów i usług (Dz.U. z 2011 r., Nr 177, poz. 1054, ze zm.), skoro podatek ten powinien zostać objęty kwotą odszkodowania należnego generalnemu wykonawcy od niesolidnego podwykonawcy" (podkreśl. H.M.).

Na podstawie powyższego należy uznać, że odmowa prawa do odliczenia przez podatnika podatku wynikającego z faktur od wykonawców zastępczych oparta jest na różnych, niekoniecznie zgodnych ze sobą, argumentach wskazywanych przez organy podatkowe i sądy:

1) nabycie nie jest związane z prowadzoną działalnością gospodarczą podatnika,

2) nabycie jest bezpośrednio związane $z$ wykonywaniem przez podatnika czynności niepodlegających opodatkowaniu podatkiem VAT, 
3) nabycie jest związane z prowadzoną działalnością gospodarczą, ale podatek VAT nie podlega odliczeniu, gdy koszty rekompensaty od niesolidnego wykonawcy powinny objąć również kwotę VAT (w sytuacji gdy wykonanie zobowiązania przez niesolidnego wykonawcę nie niosłoby za sobą obciążenia podatkiem VAT dla podatnika, co rzutuje - zdaniem sądu ${ }^{3}$ - na prawo podatnika do odliczenia podatku).

Poglądy na temat związku nabywanych przez podatnika towarów i usług w warunkach wykonania zastępczego z działalnością gospodarczą podatnika różnią się zatem w sposób istotny.

Już powyższe skłania do zastanowienia się, czy uzasadniona jest odmowa prawa do odliczenia VAT od nabycia towarów i usług w ramach wykonania zastępczego.

3. Nabycie UsŁug W RAMACH WYKonania ZastęPCZEgo ZWIĄZANE Z CZYNNOŚCIAMI NIEPODLEGAJĄCYMI OPODATKOWANIU

Nie budzi wątpliwości i pozostaje poza sporem to, że w sytuacji gdy podatnik (zamawiający) na skutek niesolidności wykonawcy zleca wykonanie, np. usług osobom trzecim, nie dochodzi do wykonania usługi na rzecz niesolidnego wykonawcy ani przez zamawiającego, ani przez wykonawcę zastępczego. Nie ma w tym przypadku wzajemności świadczeń pomiędzy dłużnikiem a zamawiającym. Podatnik (zamawiający) jest jedynym beneficjentem świadczonych w ramach wykonania zastępczego usług. Wykonanie zastępcze jest realizowane na jego rzecz. Kwoty otrzymane przez zamawiającego od niesolidnego wykonawcy mają pokryć koszt wykonania zastępczego i stanowią rekompensatę, świadczenie odszkodowawcze. Nie stanowią zatem wynagrodzenia za usługę świadczoną na rzecz niesolidnego wykonawcy, a co za tym idzie, zamawiający nie wystawia $\mathrm{z}$ tego tytułu faktury na rzecz niesolidnego wykonawcy. Zamawiający nie świadczy na rzecz niesolidnego wykonawcy żadnej czynności podlegającej opodatkowaniu w związku z otrzymywaną rekompensatą.

Trudno się jednak zgodzić $\mathrm{z}$ argumentacją prezentowaną $\mathrm{w}$ interpretacjach DKIS, że w takim przypadku mamy do czynienia z nabyciem związanym z czynnościami niepodlegającymi opodatkowaniu podatkiem VAT. Wymagałoby to uznania, że sam fakt wystąpienia o zwrot kosztów jest

${ }^{3}$ Jak wynika z cytowanego wcześniej wyroku NSA z dnia 6 lipca 2017 r., sygn. I FSK $2173 / 15$. 
czynnością niepodlegającą opodatkowaniu podatkiem VAT wykonywaną przez podatnika (zamawiającego), a dodatkowo, że dokonane przez niego nabycie zastępcze jest bezpośrednio związane $\mathrm{z}$ wystąpieniem o zwrot kosztów wykonania zastępczego. W konsekwencji należałoby zatem uznać, że otrzymanie tej rekompensaty, tj. świadczenia odszkodowawczego, jest celem samym w sobie dla podatnika dokonującego nabycia w warunkach wykonania zastępczego.

Wątpliwości może budzić także to, czy wystąpienie o zwrot kosztów wykonania zastępczego można w ogóle rozpatrywać w kategoriach czynności podlegającej lub niepodlegającej opodatkowaniu podatkiem VAT. Wystąpienie o zwrot kosztów wykonania zastępczego nie wiąże się zasadniczo ze świadczeniem na rzecz innego podmiotu - niesolidnego wykonawcy. Z drugiej strony ustawa VAT definiuje jedynie czynności podlegające opodatkowaniu podatkiem VAT, co może prowadzić do wniosku, że każda czynność cywilnoprawna niebędąca czynnością podlegającą opodatkowaniu podatkiem VAT stanowi czynność niepodlegającą opodatkowaniu. Uzyskanie zwrotu poniesionych kosztów wykonania zastępczego nie jest jednak celem samym w sobie dla podatnika. Podatnik nie nabywałby bowiem usług (towarów) u wykonawcy zastępczego, gdyby pierwotnie wybrany wykonawca (kontrahent) wykonał swoje zobowiązanie umowne.

Nie znajduje tym samym uzasadnienia twierdzenie, że dokonanie nabycia w warunkach wykonania zastępczego związane jest $\mathrm{z}$ wykonywaniem przez podatnika czynności niepodlegających opodatkowaniu. Skutkiem wykonania zastępczego jest uzyskanie zwrotu kosztów jego wykonania od niesolidnego wykonawcy (kontrahenta), ale nie jest ono dla podatnika celem samym w sobie. Celem tym jest bezwzględnie prowadzenie działalności gospodarczej.

\section{WYKONANIE ZASTĘPCZE A DZIAŁALNOŚĆ GOSPODARCZA PODATNIKA}

Nabycie usług (towarów) w trybie wykonania zastępczego jest skutkiem zaniechania wykonania zobowiązań umownych przez niesolidnego wykonawcę (kontrahenta). Nie oznacza to jednak, że zmienia się powód, dla którego podatnik chciał nabyć usługi lub towary u niesolidnego wykonawcy, a w związku z niewykonaniem przez niego zobowiązania nabywa je u wykonawców zastępczych. Nie zmienia się również ich przeznaczenie. Gdyby pierwotnie wybrany wykonawca (kontrahent) wykonał swoje zobowiązanie, podatnik nie musiałby angażować podmiotów trzecich w celu 
zrealizowania określonych czynności. Jeżeli zatem zamówione u pierwszego wykonawcy (kontrahenta) usługi lub towary miały służyć opodatkowanej działalności gospodarczej podatnika, to ich nabycie w ramach wykonania zastępczego nie zmienia tego stanu rzeczy. Powoduje jedynie, że zmienia się tylko świadczący np. usługę na rzecz podatnika oraz że świadczenia te są realizowane na koszt dłużnika (niesolidnego wykonawcy). Świadczenia te są nabywane od wykonawców zastępczych przez podatnika i on jest wyłącznym ich beneficjentem. Fakt niewywiązania się wykonawcy (kontrahenta) z umowy nie oznacza, że nagle celem dokonania nabycia od podmiotu trzeciego jest uzyskanie świadczenia odszkodowawczego od niesolidnego wykonawcy.

Wykonanie zastępcze realizowane jest niejako „w miejsce” świadczenia zaniechanego przez niesolidnego wykonawcę (kontrahenta). Nabycie takie niewątpliwie dokonywane jest w związku z prowadzoną przez podatnika działalnością gospodarczą i w celu realizacji tej działalności.

W przywołanych wcześniej indywidualnych interpretacjach podatkowych DKIS wskazuje, że podatnik, angażując podmiot trzeci (wykonawcę zastępczego), nie czyni tego w celach zarobkowych, lecz w celu uniknięcia skutków niewykonania przez wykonawcę zobowiązań wynikających z zawartej umowy. Należy się zgodzić z tym, że zaangażowanie wykonawców zastępczych ma na celu uniknięcie skutków niewykonania przez wykonawcę (kontrahenta) zobowiązań wynikających z umowy. Jeśliby jednak nabycie towarów lub usług u pierwotnie wybranego wykonawcy (kontrahenta), gdyby ten wykonał swoje zobowiązanie, było związane z prowadzoną przez podatnika opodatkowaną działalnością gospodarczą lub ich nabycie warunkowało prawidłowe jej wykonywanie (np. dzięki usługom podatnik może prawidłowo wywiązać się ze swoich zobowiązań wobec innych podatników), to zaangażowanie podmiotów trzecich (wykonawców zastępczych) potwierdza tylko bezpośredni związek pomiędzy nabyciem u nich (wykonawców zastępczych) towarów i usług a działalnością gospodarczą podatnika. Nie dokonując nabycia u wykonawców zastępczych, podatnik (zamawiający) nie mógłby właściwie, prawidłowo, wykonywać prowadzonej działalności gospodarczej.

Cel nabycia danej usługi czy towaru nie ulega zmianie wraz ze zmianą wykonawcy (dostawcy). Podatnik sięga po zakup u wykonawcy zastępczego dlatego, że potrzebuje tych towarów czy usług w prowadzonej działalności gospodarczej. Dokonanie nabycia od wykonawców zastępczych jest koniecznością wynikającą z zaistniałej sytuacji, tj. z niewywiązania się 
przez pierwotnie wybranego wykonawcę (dostawcę) z umowy. Zmienia się zatem jedynie realizujący zamówienie podatnika, ale nie cel, dla którego realizacji podatnik dokonuje tego nabycia, co do zasady.

Uwzględniając powyższe, dokonanie nabycia od wykonawców zastępczych jest związane z prowadzoną przez podatnika działalnością gospodarczą. Znajduje to potwierdzenie również w orzecznictwie sądowym (zob. wyrok NSA z dnia 6 lipca 2017 r, sygn. I FSK 2173/15, oraz wyroki WSA w Warszawie: z dnia 18 stycznia 2019 r., sygn. III SA/Wa 799/18 (CBOSA), i z dnia 13 maja 2021 r., sygn. III SA/Wa 1927/20, nieprawomocny, niepubl.).

5. Prawo podatnika do odliczenia VAT POWINNO MIEĆ PRZEŁOŻENIE NA WYSOKOŚĆ REKOMPENSATY Z TYTUŁU WYKONANIA ZASTĘPCZEGO, A NIE ODWROTNIE

Pomimo że w orzecznictwie sądowym coraz częściej można się już spotkać ze stanowiskiem, zgodnie z którym nabycie towarów i usług od wykonawców zastępczych jest związane z działalnością gospodarczą podatnika, o czym świadczą powołane wcześniej wyroki, to prawo podatnika do odliczenia podatku zapłaconego w związku z takim nabyciem uwarunkowane jest wystąpieniem pewnych okoliczności.

W wyroku z dnia 6 lipca 2017 r., sygn. I FSK 2173/15, NSA wskazał, że prawo do odliczenia VAT z faktur wystawionych przez wykonawców zastępczych zależy od tego, czy zwrot kosztów wykonania zastępczego powinien w danym przypadku obejmować kwotę podatku naliczoną przez wykonawców zastępczych czy też nie. Zdaniem sądu, gdyby wykonanie zaniechanych zobowiązań przez pierwotnie wybranego wykonawcę nie wiązało się z obciążeniem zamawiającego podatkiem VAT, niesolidny wykonawca powinien ponieść cały ciężar ekonomiczny dokonania przez zamawiającego nabycia w warunkach wykonania zastępczego, tj. łącznie z podatkiem. NSA w omawianym wyroku stwierdził, że fakt ten rzutuje na prawo podatnika do odliczenia VAT z faktur wystawionych przez wykonawców zastępczych.

Trudno się zgodzić z taką argumentacją i tezami zawartymi w przywołanym wyroku, a z pewnością z kilku co najmniej powodów należy je uznać za dyskusyjne.

Przepis art. 480 k.c. przewiduje możliwość wykonania zastępczego za zgodą sądu lub bez niej (w nagłych przypadkach) na koszt dłużnika, przy jednoczesnym zachowaniu roszczenia o naprawienie szkody. W wyniku spełnienia świadczenia na podstawie wykonania zastępczego zmienia się 
charakter świadczenia dłużnika na odszkodowawczy. Oznacza to, że jest on zobowiązany do zwrotu kosztów poniesionych przez wierzyciela $z$ tytułu konieczności wykonania zastępczego. Przy czym dzieje się tak, jeśli wykonanie zastępcze związane jest zarówno z sytuacją, w której wykonanie zobowiązania umownego przez dłużnika byłoby obciążone podatkiem VAT, jak i z sytuacją, w której nie wiązałoby się z takim obciążeniem. Uzależnienie prawa podatnika do odliczenia VAT od tego, z którą z tych sytuacji mamy do czynienia, nie wydaje się uzasadnione. Oznaczałoby to bowiem, że w jednym przypadku uznaje się nabycie w warunkach wykonania zastępczego za związane z prowadzoną działalnością, a w drugim nie. Brak uzasadnienia dla dokonania takiego rozdziału. W konsekwencji prawo do odliczenia VAT nie wynikałoby z sytuacji towarzyszącej temu konkretnemu nabyciu, lecz nabyciu, do którego przecież nie doszło.

Prawo do odliczenia VAT i warunki, jakie musi spełnić podatnik, aby móc skorzystać z tego prawa, określają ściśle przepisy ustawy VAT. Jedynie $\mathrm{z}$ tych przepisów powinno być więc wywodzone prawo podatnika do odliczenia VAT w związku z dokonanym przez niego nabyciem towarów i usług. Zgodnie z art. 86 ust. 1 ustawy VAT podatnikowi przysługuje prawo do odliczenia kwoty podatku w zakresie, w jakim nabycie towarów i usług związane jest z czynnościami opodatkowanymi.

Warunkiem odliczenia jest zatem istnienie związku pomiędzy tym konkretnym nabyciem a opodatkowaną działalnością gospodarczą podatnika. Związek taki albo istnieje, albo nie, i trudno zgodzić się z tezą, że jest uzależniony od tego, czy zamawiający zostałby obciążony podatkiem, dokonując nabycia w innych okolicznościach, dokonując nabycia u innego podmiotu. Wówczas więc, gdy nabycie towarów i usług jest związane $\mathrm{z}$ opodatkowaną działalnością gospodarczą podatnika, należałoby uznać, że podatnikowi przysługuje prawo do odliczenia VAT z faktur otrzymanych od wykonawców zastępczych. Fakt ten natomiast powinien mieć przełożenie na określenie wysokości kosztów wykonania zastępczego (rekompensaty), którymi obciążony zostanie niesolidny wykonawca. Nie odwrotnie. Obciążenie niesolidnego wykonawcy kosztami wykonania zastępczego powinno dotyczyć wyłącznie kosztów koniecznych związanych z wykonaniem zastępczym ${ }^{4}$. Koszty te wynikają również z tego, czy podatnikowi

${ }^{4}$ Zob. R. Tanajewska, Komentarz do art. 480 k.c., [w:] Kodeks cywilny. Komentarz aktualizowany, red. J. Ciszewski, P. Nazaruk, stan prawny: 30 lipca 2019 r., LEX (dostęp: 7.10.2020 r.). 
przysługuje prawo do odliczenia podatku czy nie. W przeciwnym razie, tj. w sytuacji, gdy podatnik przerzuca na wykonawcę kwotę podatku w związku z dokonanym nabyciem od wykonawców zastępczych, tj. gdy nabycie to jest związane z jego opodatkowaną działalnością gospodarczą, dochodziłoby do przerzucenia na wykonawcę kosztów, które wcale nie są konieczne.

Wysokość świadczenia odszkodowawczego od niesolidnego wykonawcy powinna być określana $\mathrm{z}$ uwzględnieniem przysługującego podatnikowi, bądź nie, prawa do odliczenia VAT z faktur od wykonawców zastępczych, tj. uzależniona od istnienia związku pomiędzy konkretnym nabyciem towarów lub usług a czynnościami opodatkowanymi u podatnika. Jeżeli taki związek istnieje, kwoty VAT, którymi zostało obciążone takie nabycie towarów i usług, nie powinny być uznane za koszt podatnika, skoro w świetle przepisu art. 86 ust. 1 ustawy VAT mogą one pomniejszyć u niego kwotę podatku należnego. W efekcie kwoty VAT nie obciążą podatnika. W przeciwnym razie to nie przepisy podatkowe określałyby prawo podatnika do odliczenia VAT, ale przepisy Kodeksu cywilnego, a w zasadzie przyjęta interpretacja co do rozumienia pojęcia „kosztów”, o których mowa w art. 480 k.c., z czym trudno się zgodzić. Poza tym pojęcie tych kosztów nie zostało $\mathrm{w}$ omawianych przepisach zdefiniowane. Nie ma powodów, dla których koszty te należałoby określać bez uwzględnienia prawa podatnika do odliczenia VAT.

Przyjmując, że nabycie w warunkach wykonania zastępczego jest związane $\mathrm{z}$ opodatkowaną działalnością gospodarczą podatnika (na co wskazuje również NSA w wyroku z dnia 6 lipca 2017 r., sygn. I FSK 2173/15, a także wyroki WSA w Warszawie: $z$ dnia 18 stycznia 2019 r., sygn. III SA/Wa 799/18, oraz z dnia 13 maja 2021 r., sygn. III SA/Wa 1927/20), w konsekwencji podatnik powinien mieć prawo do odliczenia VAT w związku z dokonanym nabyciem. VAT nie powinien być uznany za ciężar, koszt, który poniósł nabywca w związku $\mathrm{z}$ wykonaniem zastępczym, skoro podatek ten powinien, co do zasady, podlegać odliczeniu - zob. wyrok Sądu Apelacyjnego w Katowicach z dnia 20 października 2015 r., sygn. V ACa 169/15 (Portal Orzeczeń Sądów Powszechnych).

W orzecznictwie można się też spotkać ze stanowiskiem, w świetle którego prawo podatnika do odliczenia VAT w związku z dokonanym nabyciem od wykonawców zastępczych zależy od sposobu kalkulacji kwoty rekompensaty od dłużnika. W wyroku z dnia 13 maja 2021 r., sygn. III SA/Wa 1927/20, WSA w Warszawie wprawdzie podzielił stanowisko podatnika co do istnienia związku nabycia usług od wykonawców zastępczych z opodatkowaną 
działalnością gospodarczą podatnika i uznał, że przysługuje mu prawo do odliczenia podatku w związku z tym nabyciem, to jednocześnie wskazał, że w sytuacji otrzymania przez Spółkę rekompensaty od wykonawcy, obejmującej także równowartość VAT poniesionego przez Skarżącą przy nabyciu usług, nie będzie ona uprawniona do odliczenia VAT z faktury wystawionej przez wykonawcę zastępczego. $Z$ takim poglądem trudno się jednak zgodzić. Zaakceptowanie tego rozwiązania skutkowałoby uznaniem, że prawa podatnika do odliczenia VAT nie regulowałyby ani przepisy dyrektywy $\mathrm{UE}^{5}$, ani ustawa VAT, ale zależałoby ono od decyzji podatnika co do kalkulacji kwoty rekompensaty.

Oczywiste jest, że podatnik nie może odliczyć kwoty VAT od nabycia towarów lub usług ani przenieść ekonomicznego ciężaru VAT na niesolidnego wykonawcę w kwocie wyliczonej rekompensaty. Nie oznacza to jednak, że prawo podatnika do odliczenia VAT może zależeć od wyboru podatnika co do sposobu kalkulacji kwoty rekompensaty.

Jeżeli uznamy, co potwierdzają przywołane wyroki, że nabycie od wykonawców zastępczych jest związane z prowadzoną, opodatkowaną działalnością gospodarczą podatnika, to kalkulacja kwoty rekompensaty nie zmienia tego stanu rzeczy (istnienia tego związku). Kwota rekompensaty natomiast powinna być uzależniona od tego, czy podatnikowi przysługuje prawo do odliczenia podatku czy nie.

\section{Podsumowanie}

Dokonanie przez podatnika VAT nabycia towarów lub usług w warunkach wykonania zastępczego jest wynikiem niewywiązania się wykonawcy z umowy. Nie oznacza to jednak, że ulega zmianie cel nabycia towarów lub usług przez podatnika.

Brak uzasadnienia do uznania, że dokonanie przez podatnika VAT nabycia w warunkach wykonania zastępczego z założenia nie jest związane z opodatkowaną działalnością gospodarczą podatnika, lecz z czynnościami niepodlegającymi opodatkowaniu.

Jeśliby nabycie towarów i usług od pierwotnie wybranego wykonawcy (kontrahenta) w sytuacji, gdyby wykonał on swoje zobowiązanie umowne, było uznane za związane $\mathrm{z}$ opodatkowaną działalnością gospodarczą

${ }^{5}$ Dyrektywa 2006/112/WE w sprawie wspólnego systemu podatku od wartości dodanej (Dz. Urz. UE L 347.1 z 2006 r.). 
podatnika, to nabycie w ramach wykonania zastępczego jest także związane $\mathrm{z}$ opodatkowaną działalnością podatnika.

Fakt realizacji wykonania zastępczego na koszt dłużnika nie oznacza, że uzyskanie od niego świadczenia odszkodowawczego jest dla podatnika celem samym w sobie. Podatnikowi powinno zatem przysługiwać prawo do odliczenia VAT z faktur otrzymanych od wykonawców zastępczych (oczywiście jeżeli nie występują przesłanki negatywne do dokonania takiego odliczenia określone w art. 88 ustawy VAT, np. faktury wystawione przez wykonawców zastępczych są fikcyjne).

Prawo podatnika do odliczenia VAT z tytułu nabycia towarów i usług, a także przesłanki warunkujące skorzystanie z tego prawa regulują przepisy dyrektywy UE i ustawy VAT. Prawo to przysługuje podatnikowi, co do zasady, w zakresie, w jakim nabyte towary i usługi są związane z opodatkowanymi czynnościami podatnika.

Za dyskusyjne należy uznać spotykane w doktrynie poglądy wskazujące na to, że pomimo związku nabycia $\mathrm{z}$ opodatkowaną działalnością podatnika prawo do odliczenia VAT z faktur od wykonawców zastępczych uzależnione jest od tego, czy w sytuacji, gdyby wykonawca wywiązał się z zawartej umowy, nabycie od niego towarów lub usług było obciążone VAT. Podobnie nie znajduje uzasadnienia pogląd, zgodnie z którym prawo do odliczenia VAT od nabycia w warunkach wykonania zastępczego zależy od kalkulacji kwoty rekompensaty od dłużnika.

Jeżeli nabycie w warunkach wykonania zastępczego jest związane z prowadzoną opodatkowaną działalnością gospodarczą podatnika, to podatnikowi powinno przysługiwać prawo do odliczenia VAT. Prawo do odliczenia kwoty podatku powinno być rozpatrywane w odniesieniu do konkretnego nabycia (od wykonawcy zastępczego), a nie w odniesieniu do nabycia, do którego nie doszło. Jeżeli nabycie jest związane z opodatkowaną działalnością podatnika, to kalkulacja kwoty rekompensaty nie może stanowić przesłanki określającej prawo do odliczenia podatku. Oczywiste jest, że podatnik nie może jednocześnie odliczyć kwoty VAT od nabycia towarów lub usług oraz przenieść ekonomicznego ciężaru VAT na dłużnika w kwocie wyliczonej rekompensaty.

Jednakże to raczej przysługujące (albo nieprzysługujące) podatnikowi prawo do odliczenia VAT powinno mieć wpływ na wysokość świadczenia odszkodowawczego - nie odwrotnie. 


\section{BIBLIOGRAFIA}

Czerwiński M., Zwrot kosztów wykonawstwa zastępczego jako czynność nieobjęta ustawa o podatku od towarów i usług. Glosa do wyroku NSA z dnia 9 września 2016 r., I FSK 262/15, „Państwo i Prawo” 2017, nr 4.

Malinowski M., Nie można odliczyć VATu $z$ faktury wystawionej przez podwykonawce zastępczego, LEX/el. 2017.

Rogowska-Rajda B., Tratkiewicz T., Prawo do odliczenia VAT wświetle orzecznictwa TSUE, Warszawa 2018.

Tanajewska R., Komentarz do art. 480 k.c., [w:] Kodeks cywilny. Komentarz aktualizowany, red. J. Ciszewski, P. Nazaruk, stan prawny: 30 lipca 2019 r., LEX (dostęp: 7.10.2020 r.).

\section{SubSTITUTE PERFORMANCE AND DEDUCTION OF VAT}

Summary. The subject of the article are issues related to the right to deduct tax on goods and services (VAT) in connection with the purchase by a VAT payer of goods or services from substitute contractors. The author indicates many doubts arising from the position taken in this case by the tax authorities, which question the taxpayer's right to deduct VAT in such cases. Moreover, she points out that the position adopted by the tax authorities, according to which the purchase of goods and services from substitute contractors is by definition not related to the taxpayer's business activity, but to activities not subject to VAT, and consequently VAT on purchased goods and services is not deductible - is wrong. The article indicates that the acquisition under the conditions of substitute performance is related to the taxpayer's business activity and directly serves the implementation of this activity. The purpose of the goods and services purchased by the taxpayer does not change. If the purchase of goods or services from the initially selected contractor would be related to the taxpayer's business activity, the acquisition of goods or services from substitute contractors will also be related to this activity. The change of the entity providing services (providing the delivery) does not change the purpose of their purchase by the taxpayer or their relationship with the business activity conducted by him. The taxpayer should be entitled to deduct VAT in connection with the acquisition under the conditions of substitute performance. The taxpayer's right to deduct VAT should translate into the amount of compensation from the debtor (unreliable contractor) for substitute performance, and not the other way around.

Keywords: VAT, substitute performance, tax deduction, compensation 